\title{
The Lifelong Learning Sector and the Development of Hong Kong as A Regional Education Hub: Is Government Policy Rhetoric or Reality?
}

\author{
John Cribbin \\ School of Professional and Continuing Education \\ University of Hong Kong \\ 11/F T.T. Tsui Bldg, Pokfulam, Hong Kong \\ Tel: 852-2975-5747Ｅ-mail: john.cribbin@hkuspace.hku.hk
}

\begin{abstract}
In this article the researcher sets out to investigate the development of lifelong learning policy in Hong Kong. The policy analysis is focused specifically on the Hong Kong Government's policy for Hong Kong to be a Regional Education Hub. Qualitative data was gathered using questionnaire surveys of leading local and overseas lifelong learning providers, through semi-structured interviews with experts who are leading practitioners in the field, and, through analysis of policy documents. The research highlights the extent of non-local provision of higher education in Hong Kong by the lifelong learning sector in association with overseas institutions. The study also shows that despite the policy rhetoric Hong Kong could not currently be described as a regional hub for education although all those experts surveyed consider Hong Kong well placed to develop as an education hub and were surprised that more has not been done.
\end{abstract}

Keywords: Hong Kong, Lifelong learning, Marketization of higher education, Human capital

\section{Introduction}

The thesis study set out to consider the development of the Hong Kong Government's policy for Hong Kong to be a Regional Education Hub, the effectiveness of government policy towards achieving that end and the implications for the lifelong learning sector. A number of specific research questions were identified and these will be dealt with in turn below. In addressing these questions a largely qualitative approach was adopted, obtaining information through questionnaire surveys of leading providers from overseas and from local operators, through interviews with experts who are leading practitioners in the field and through analysis of policy development. There was also the collection and synthesis of factual documentary data on overseas programmes offered in Hong Kong. The key issues and concepts from the social sciences underpinning the study included human capital theory, social capital theory, globalisation and trade in educational services, marketization versus regulation and policy analysis. This paper will assess the extent to which these questions have been answered and what contributions the study can offer to our knowledge and understanding of the effects of government policy on lifelong learning in Hong Kong.

\section{The lifelong learning sector in Hong Kong}

It may be timely at this point to define what is meant by the lifelong learning sector in Hong Kong. It has been described in this study as the fourth estate of education (after primary, secondary and tertiary education) and is seen as principally Hong Kong focussed. The sector has its roots in University extra-mural departments along the UK pattern established in Hong Kong from the 1950s which aimed at adult, continuing and professional education. It therefore covers a wide range of programmes ranging from general interest to second chance education and courses leading to professional qualifications. In the 1990s there was rapid expansion to offer more award bearing programmes and in particular a growth of programmes leading to overseas awards. Almost all HK universities have continuing education units that offer such courses and from the mid-1990s, by government policy decision, these courses were all obliged to be self-financing. There are 8 universities with public funding coordinated by the University Grants Committee (UGC) and 2 universities that receive no direct public funding,

In addition, there is extensive private sector development with many private companies, formed as Colleges, mostly small scale but with some larger institutions of which a few are offering programmes or representing overseas institutions as well as public and private programmes offered by quasi-public institutions such as the Vocational Training Council and Caritas, a Catholic Church body. 
Prior to 2000 much of this activity was for part-time students but since 2000 this lifelong learning sector has played a significant role, particularly within some of the UGC funded institutions, and has developed self-financed community colleges to meet the government's post-secondary expansion targets for full-time students in the 17-21 year age cohort. Moreover, this expansion, to Associate Degree and Higher Diploma level, has generated more demand for tertiary places to first degree level which can only be fully met through self-financed first degrees offered in Hong Kong by local or overseas institutions. The additional full-time provision has also given the lifelong learning sector enhanced capability to offer places to non-local students and as a sector it is both competitive and entrepreneurial. There is a willingness to attract non-local students if possible. Moreover, some institutions within the sector, particularly HKU SPACE, the Open University of Hong Kong and Baptist University School of Continuing Education are involved in development in China Mainland and also have interest in the export of programmes. In this context, the government's 2008 policy announcements which do not mention export of programmes, in contrast to the 2006 policy statement, are somewhat confusing as to whether priorities have changed. A feature of the vagueness of government policy announcements and speeches on Regional Education Hub is that there is some confusion in the interpretation of priorities as these are not clearly stated and have not been debated with the stakeholders.

The relationship of the sectors is shown graphically below.

Insert Figure 1 Here

\section{Methodology and Literature Review}

In terms of methodology, the thesis is based on a qualitative rather than a quantitative approach. The political economy of education forms the main framework for the study which draws in particular on human capital theory and social capital theory. It also draws on policy analysis, globalization, marketization and regulation, the trade in educational services and policy analysis to address the research questions.

The research methods principally involved:

(i) collection and analysis of data from the annual reports submitted to the Registrar of Non-local Higher Education Programmes. These are required under the Non-local Ordinance and applies to courses in partnership with local universities (exempted courses) and those offered by overseas institutions with private providers (registered courses). The data comprises student enrolments, by level of programme, numbers of graduates and fees paid for the years 1999 and 2005; the scale of these is as follows:

\begin{tabular}{|l|l|l|l|}
\hline & \multicolumn{2}{|l|}{ Programmes } & Students \\
\hline & Exempted & Registered & \\
\hline 1999 & 190 & 114 & 28,002 \\
\hline 2005 & 310 & 342 & 49,990 \\
\hline
\end{tabular}

(ii) a questionnaire survey of some 50 overseas and 15 local institutions involved in offering overseas programmes in Hong Kong; the overseas institutions were partners of HKU SPACE. Response rates were $46 \%$ for overseas institutions and $67 \%$ for local institutions.

(iii) structured in-depth interviews with 10 experts considered as authoritative in the field;

(iv) policy analysis of the government's processes in developing the education hub policy; principally through reference to the annual Chief Executive's Policy Address, supporting documents and Legislative Council education panel debates and briefing papers.

(v) documentary sources on provision of overseas or Hong Kong courses of study in the Pearl River Delta Region.

A sample from the Literature Review in terms of the key issues and concepts underpinning the study is given in the following:

Human capital theory is of direct relevance in studies that relate to lifelong learning provision, particularly where this is, as in Hong Kong, financed largely by individuals rather than the state. The salience of the theory was initiated by Theodore Schultz and Gary Becker (Woodhall, 1997) and later by Kerr (1962,1971). It may also be regarded as linking education and the labour market (Belfield 2000). The work of the Leicester University group on education and training in particular is relevant (Ashton and Green 2006, Ashton et al, 1999) whilst for the Asian region the work of Tilak $(2001,2003)$ is referred to and more specifically for Hong Kong there are a number of references (Siu et al 2005, Cheung, Ho and Liu 1994). While human capital theory is perhaps not 
uncritically established as the principal explanatory model it certainly exerts a strong influence on education and training and hence lifelong learning.

Social capital theory is also related particularly with reference to learning (Putnam, 2002, Field 2005) which connects communities of learners and their groups/networks (Coleman 1997). In any study that involves the movement of goods and people, the concept of Globalisation has to be addressed and has been done so effectively by a wide range of authors (Mok and Tan 2004, Ashton and Green op.cit, Jarvis 2002, Marginson, 1999, Ashton 2002). Aspects of branding as applied to education were identified as potentially relevant (Reich 2004) as well as the implications of massification, i.e. the move to mass higher education systems (Wolf, 2002). In terms of Hong Kong and China, there is also the issue of the role of Hong Kong as the gateway to and from China and their mutual influence upon each other (Postiglione 2003). In relation to the trade in educational services concept the main issues in terms of its characteristics, volume and economic importance have been identified by Marginson (2006), Knight (2002, 2003), Johnes (2004) and Naidoo (2007). The role of government, particularly in terms of self-funded or private provision of educational services and in terms of marketization and regulation are also relevant and have been strongly identified in Mok (2005) and Mok and Currie (2002). In terms of policy analysis as applied to the Hong Kong government the key references are Burns (2004) and Scott (2005).

\section{The Research Questions}

\section{Why and how was the policy developed?}

It was identified that the genesis of the policy lay with a University Grants Committee report in 1996. This report, Higher Education in Hong Kong, surveyed the whole higher education sector, including Continuing and Professional Education, and concluded, inter alia, that Hong Kong should aim to become a regional centre for higher education, recognising that it had advantages as a place where East and West met but also that it would face competition in developing this role (UGC, 1996). Judged purely by developments in the funded university sector there has been some success given that the numbers of overseas students in Hong Kong's universities has risen to some $10 \%$ of total funded student enrolment from a low base in the fourteen years from 1996. Further reports in 2002 and 2004 supplemented the aim to increase non-local numbers and the "hub" term was first used by the University Grants Committee in the 2004 report (UGC, 2002, 2004). Generally, the term came into wider use in 2004 being quoted in speeches by the Secretary for Education and used by the Education Bureau in its briefings and on its website from 2005 .

Arising from the interviews and the responses to the questionnaire survey, there was widespread agreement that the education hub policy is a sensible one. If anything, there is surprise that more has not been achieved in making it a reality. Perhaps it is because the policy is a self-evident one that there has been little public debate on how it can be achieved. The Hong Kong government approach of laissez-faire or positive non-intervention may also be responsible for the lack of debate or consultation since it is likely that it is a policy that would not involve public resources or funding. Hence, government support would be exhortatory rather than concrete. On the other hand, there are aspects of the policy that government may not wish to highlight given that an increase in non-local student numbers may draw attention to the relative lack of funded tertiary education places which are still limited for local students.

The pressure on this aspect has somewhat eased in recent years with the significant expansion of self-financed post-secondary places since 2000 and the fact that of the new $20 \%$ quota from 2008 for non-local students over and above the funded number of places, the vast majority (80\%) are not funded places. Even so, the expansion of post-secondary places is fuelling further demand for senior tertiary places which may cause tension if local students perceive that the non-local proportion is expanding at their expense. The vague pronouncement therefore of the regional education hub policy as a good thing serves both to avoid potential commitments on government and to avoid potential controversy. To the extent that there is progress, government can claim success, to the extent that there is a lack of progress it can be blamed on the institutions.

This may be a too cynical reading of the situation but it is certainly the case that the formulation and development of the hub policy has to date not followed the usual routes and has lacked specificity.

\section{How does the policy impact on the lifelong learning sector in particular?}

As stated above, the policy emanated from the universities funding body in a 1996 report and was conceived of in terms of expanding full time undergraduate and postgraduate numbers.

There is a strong financial pressure on the lifelong learning sector that is not only derived from the self-financing nature of the operations. The community college development that has produced a capacity of over 25,000 
full-time places since 2000 has been supported indirectly by government through the provision of land grants and ten-year interest free loans to assist campus development. Five sites have been developed and some institutions have taken loans to acquire and convert commercial premises for teaching. In total, about HK\$4 billion of an available fund of HK\$5 billion has been taken up by the sector in loans meaning that the sector has to ensure the repayment of HK\$400 million each year over the ten year period. This can only be recovered through student fees or bridge financing from banks if the loan is to be spread over a longer period. The twenty community colleges thus compete for students and already two have failed, others may be marginal. The possibility inherent in the hub policy of attracting students from overseas, especially from China Mainland, is important in order to ensure that operations are financially viable. Although such recruitment is now possible the restraining factor of student accommodation is a factor as parents from China generally expect this to be provided. There is therefore some urgency for government to act in respect of the accommodation issue and in parallel some institutions have had the loan repayment period extended to twenty years. The hub policy is thus a matter of some importance as, even given this time extension, some institutions will be at financial risk if student numbers cannot be increased. Given the competitive environment there is little scope to raise fees as a means of increasing income.

Those institutions that export programmes to China had also hoped for more assistance from government in facilitating operations in the mainland. This would take the form of seeking permission to be treated as a Chinese rather than an overseas institution and in seeking eligibility for government matching funds to support exchange programmes since active institutions could benefit from this, notably the operations in Zhuhai (Baptist University) and Suzhou (HKUSPACE) which both offer full time studies. The policy does therefore have implications for the sector.

\section{What are the factors that will affect the policy becoming a reality?}

In terms of students being attracted to Hong Kong the city can offer a number of advantages. The city itself is a lively and attractive location and the policy seeks to capitalise on this - Asia's world city - as well as it being a gateway to China and a place where East and West meet. It can therefore attract students from the Mainland as well as from the rest of the world and this in itself would be one of its attractions. For students it is not expensive in terms of daily living costs or fee levels but there is the critical issue of affordable accommodation. The expansion of overseas student numbers has been relatively rapid in the past three years to reach the present total of some 8,400 in 2008/9 in the mainstream universities but further growth (the current quota allows this number to double) will not be possible without government action on student accommodation. There is scepticism in the institutions that this can be solved by one massive development as this would risk becoming an overseas student ghetto and, in any event, one location is unlikely to suit all the institutions.

The situation in Hong Kong can be contrasted with Singapore which has over 90,000 overseas students in a territory with a smaller population than Hong Kong and a smaller land area (about two thirds the size in both cases). How Singapore has achieved this may be instructive but such a study is outside the scope of this paper. It should also be noted that Malaysia has some 70,000 overseas students (2008) and aims to increase this to over 100,000. A negative factor in Hong Kong may be the lack of financial incentive and financial pressure for the mainstream institutions to expand overseas student numbers significantly. There is also the constraint of the strictly controlled number of funded places and the reluctance to create a perception that places are being offered to overseas students rather than local students. Student exchange may solve this potential problem but may not result in a large scale of activity. Immigration policies are also restrictive and cumbersome which does not encourage growth in overseas student numbers.

\section{To what extent is the policy based on a realistic assessment of the higher education provision in Hong Kong?}

The data collection exercise undertaken in the study has demonstrated the extent of overseas degree provision in Hong Kong as far as student numbers, graduates and fees paid are concerned for the years 1999 and 2005. At the time of the study (2007) the 2005 data was the latest complete set available. This is publicly available information but as far as is known had not previously been collated and presented. It shows that the local institutions fail to meet local demand by a significant margin. By 2005 there was an equivalent number of Masters level students and half the number of Bachelors graduates each year as compared with the funded sector. The fees generated by these students exceeded those paid in the funded sector. This begs the question that a higher education system that cannot meet its local demand is unlikely to be in any position to develop as an education hub as it suggests that there is no spare capacity. This may be a false conclusion given that the capacity of the local funded system is artificially capped by government policy. Government might also wish to justify its position as being in line with its laissez-faire philosophy and that the market mechanism has come into 
play to meet demand. Whilst this may be the case there is no evidence that government takes statistics on the market-led provision into account in its planning for higher education provision. Nowhere has government published statistics on the overseas registrations even though these are available and nor has it reported figures on the complete extent of lifelong learning provision in its annual reports. Partly, of course, this is because the latter figures are not easy to establish given the competitive nature of the provision since providers are reluctant to disclose sensitive market information. Key features of these statistics are attached as Annex I.

The education hub policy was generated from the university funding body and makes sense in the context of that sector. The permitted scale, at a $20 \%$ quota of funded numbers, is not excessive in comparison to practices in other countries. The financial incentives are not pronounced but this has the advantage that institutions are driven more by motives of internationalisation per se more than by the desire to attract additional resources. On the other hand, the lifelong learning sector, which would be prepared to react more entrepreneurially in promoting the hub concept, both onshore and offshore, has not really been taken into account in the policy pronouncements. This is partly because the activities of the sector are not well understood by government. The success of the sector in meeting government targets for the doubling of the post-secondary opportunities has made government more aware and the introduction of the Qualifications Framework and more overt quality assurance mechanisms (the reformed Hong Kong Council for Accreditation of Academic and Vocational Qualifications (HKCAAVQ), the Joint Quality Review Committee (JQRC), and the UGC Quality Assurance Council respectively) indicates that marketization and regulation are being employed to bring in more control.

5. Is there a tension between the operation of a free market and the inclination of the Hong Kong government to regulate (especially in education) and how does this affect the policy?

The traditional education sectors funded by government, primary, secondary and tertiary, are highly controlled in Hong Kong. What has emerged in recent years as the lifelong learning sector or fourth estate, has not been so regulated. The expansion of the sector during the 1990s made its activities more visible and the Open University of Hong Kong then argued that the partially subsidised continuing education activities of the funded universities were unfairly competitive to its self financed operation. In typical fashion, to create a level playing field, government decreed that all continuing education activities become self-funded from the mid-1990s (Cribbin, 2002). In 1998, in terms of overseas programmes, the Non-Local Ordinance came into effect and was designed as consumer protection against rogue institutions. It applied to all providers, quasi-public and private. These were still relatively light touch measures. The establishment of community colleges from 2000 to deliver on government's aspirations to double the intake to post secondary education brought the sector into even more prominence and highlighted the different treatment accorded to the self-accrediting sector (the universities) and the non self-accrediting sector which had to seek approval from the Hong Kong Council for Accreditation of Academic and Vocational Qualifications (HKCAAVQ). This process was both time consuming and costly.

Once again, government felt obliged to ensure a level playing field. Guidelines for Associate Degrees and Higher Diplomas were belatedly introduced. In addition the HK Qualifications Framework (QF) was introduced to regulate the sector more closely. Vetting of programmes to appear on the Register is to be done by HKCAAVQ which is the Registrar of the QF but for the self-accrediting sector a universities owned body, the Joint Quality Review Committee, has been created. The processes for the two sectors are similar as is the case for the operation of the Non-local Ordinance. A further factor is the government's provision of funding for students in the expanded provision and also support for institutions in the form of land grants and development loans. These also bring with them stringent reporting conditions and obligations so that the market led provision is increasingly regulated. It is against this backdrop therefore that the education hub policy has developed. It has been demonstrated that there appears to have been little discussion of the policy and certainly no detailed analysis of its implications. Yet, it is widely regarded as a good thing. For the lifelong learning sector it represents opportunity but there are still barriers to be overcome while the creeping tide of regulation that has caught up with the sector's other activities suggests that if government does involve itself actively in the promotion of the policy then there will inevitably be more controls involved.

6. What is the significance of the policy for Hong Kong and for China Mainland respectively (particularly the Greater Pearl River Delta region, including Macao)?

The significance for Hong Kong of the policy is related firstly to the attraction of talent - brain gain. The expert interviews touched on this theme which is related to government's perception of remaining competitive in the knowledge economy and as part of Hong Kong's ethos as Asia's World City. There are also the advantages of Hong Kong as a gateway to China and as a window on the west for China, as a part of China while yet an international or global city and attracting talents and students from both China and the rest of the world. Hong 
Kong can also claim facility in both Putonghua and English although both need to be, and would be, strengthened through more engagement of overseas and mainland students.

For the tertiary institutions the attractions are related to internationalisation generally and in attracting high quality students in the belief that both local and international students benefit from such a mixed learning environment. Indeed, the genesis of the policy emanated from the universities funding body and it has supported implementation such that nearly $10 \%$ of numbers are from overseas and a target of $20 \%$ is accepted. At the institutional level this is sufficient to make a difference and compares with practices elsewhere, for example, Stanford has a limit of $6 \%$, Bristol of $15 \%$ (Thomas, 2007). There is no strong financial imperative for the Hong Kong tertiary institutions to internationalise because funding is not threatened and the fee differentials are not as wide as in some other jurisdictions. However, the lifelong learning sector, being self-financed and entrepreneurial, would be more driven by the fiscal returns that might be made from the education hub development. As has been demonstrated, resources are already stretched through borrowing to meet government's expansion targets and there is now more capacity to meet the local demand. Hence expansion of overseas numbers or export of programmes overseas would be welcome.

China Mainland is the most likely area where Hong Kong may aspire to be an exporter of education programmes. Indeed, there are already a number of programmes offered in the mainland and two campus developments. In this context Hong Kong compares well with the major players (Young and Lee, 2007). This is in spite of the fact that Hong Kong is treated in the same way as any other overseas provider and, in fact, it could be said that this is in spite of the education hub policy since it has been of little assistance in respect of developments that have taken place. For example, some institutional links pre-date the policy and calls for government to extend the Closer Economic Partnership Agreement to education or to include education more actively under the Greater Pearl River Development Council's work have not thus far borne fruit. There may be reluctance by the mainland government to open up more to overseas provision in view of concerns on quality and in the context of very rapid expansion of domestic provision, graduate unemployment and the need to attract specific expertise rather than expansion of opportunity per se ( $\mathrm{Li}$ and Morgan, 2008). On the other hand there is significant pressure because of rising prosperity and the one child policy for parents to seek maximum opportunity for that one child to acquire a university qualification. Lifelong learning and continuing education at higher academic levels are only just beginning to emerge as priorities after traditionally being associated with adult remedial work. It is interesting also to note the view expressed in one of the interviews that Hong Kong may be regarded as one of three education hubs in China along with Shanghai and Beijing. The notion of cities as education hubs may be one that has some resonance for Hong Kong This concept has been developed by the Higher Education Task Force for Melbourne as the "Global University City Index" based on a number of factors and Hong Kong is ranked 14 in this context (Gardner, 2006).

It is certainly somewhat surprising that there has not been more development in the Pearl River Delta area. It appears that a number of factors may be involved. First, the cities of the region are competitive and would not necessarily welcome Hong Kong initiatives or leadership. Secondly, Hong Kong institutions prefer to collaborate with top universities and these are concentrated in Shanghai and Beijing. Thirdly, the general barriers to working in the mainland also apply to the Pearl River Delta area and the geographical links are not markedly easier than with other parts of China as rail links have been limited as is convenient road access. This is not to say there are not links as the major initiative in Zhuhai demonstrates although this is a partnership with a renowned Beijing institution. There are also links with Zhongshan University, the leading national university in Southern China. That there are not extensive links in Shenzhen, physically adjoining Hong Kong, is surprising but these are developing as there have been numerous explorations of such possibilities and there are established research links. As for Macao, the developments have also been limited and this may partly be a feature of demand since the population is only some half a million and there are established local institutions. The rapid development of the gaming industry in recent years has increased the number of service jobs so there are signs that a demand for continuing education may increase. Nevertheless, for there to be a significant expansion of provision by Hong Kong institutions in the immediate region some help from government to promote such 'export' may be required. This may now be forthcoming as education was in 2009 recognised as one of six "pillar industries" for future development.

7. How do Hong Kong's ambitions to become a regional education hub fit in the regional and global context of trade in educational services?

The current scale of Hong Kong's education hub activities can only be described as modest, some 8,400 overseas students in Hong Kong and about the same number of students following Hong Kong courses in China Mainland. Both these numbers are overshadowed by the number of students taking imported overseas programmes in Hong 
Kong $-50,000$ (established by this research for 2005) and by the number of Hong Kong students studying overseas and in China Mainland - 66,700 (Wong, 2005). The numbers are also modest set against the scale of the major hubs in the USA, UK and Australia. Even within the region they are overshadowed by Singapore (an estimated 90,000) and tiny Macao $(14,000)$. In terms of resources to support the hub policy there is also only a modest provision via matching funds for donations to universities which may in part be used to fund overseas student scholarships. The UK and Australian governments in contrast spend very heavily on the promotion of their higher education sectors to overseas students and Hong Kong is unlikely to be able to compete on this scale.

It may also be unrealistic to expect that it should be able to compete on this scale. It would be more realistic to compare with Singapore and New Zealand and perhaps with other city hubs. It should also be emphasised that Hong Kong has started from a small base and that its development in terms of the limited ambitions set by the University Grants Committee as the progenitor of the hub policy has been reasonably successful. As one of the interview comments suggested it may be that Hong Kong should concentrate on niche roles rather than harbouring ambitions to compete with the heavyweights.

In fact the Trade Development Council's Study (TDC, 2005) gives an analysis of Hong Kong's strengths and weaknesses (the latter mainly being relatively unknown outside Hong Kong and the current visa restrictions) and proposed the $20 \%$ quota for universities that has now been adopted for 2008/9 with no limits for the self funded sector where restrictions still apply. For inbound students, growth to a target of around 20,000 was suggested as realistic including both the funded and self-funded sectors. The Council was willing to assist in this promotion and has recently worked with the universities in promotion in South Asia. This is one of the few concrete references to what might be achievable and none of the policy pronouncements by government mention specific targets, apart from the $20 \%$ quota figure for 2008/9. Indeed, as mentioned above, it is difficult to follow priorities within the policy and to know, for example, whether omission of a specific reference to the export of education and the encouragement of private overseas universities in the 2007 Policy Address supplement heralds a change of policy or whether it has no particular significance. The conclusion would be that consideration of realistic targets and how to achieve these would be a helpful initiative by government rather than the somewhat vague formulations to date. A more recent study (Cheng et al, 2009) confirms these trends and recommends that a responsible government agency be appointed to further the education hub concept.

\section{How effective is Government Policy and what are the implications for Lifelong Learning?}

The development of Hong Kong as a regional education hub has become a government policy almost by stealth in that its policy context and implications have not, apparently, been fully debated. The idea of the internationalisation of the city's university campuses was the basis of the policy. This was articulated by the university funding body in a forward looking review in 1996 and, in the following fourteen years has in many respects been implemented since it was never envisaged as a large scale activity. Such would have been impossible given that government funds university places for only $18 \%$ of the age cohort and shows no sign of changing that policy. Providing a small proportion of that $18 \%$ provision for overseas students is probably acceptable to the Hong Kong taxpayer but anything beyond that could be seen as unacceptably denying places to local students. Since the additional overseas quota is at a fee level much closer to marginal cost than full cost it is evident that there is some cross-subsidy but this does not seem to have become a public policy issue.

At about the same time, in 1996, the continuing education provision within universities was determined by government to become self-financing. The sector was already growing in response to community demand during the 1990s and so this move did not have a serious impact on the volume of activity. Arguably it may have led to the provision of courses to become rather more instrumental than it would have been without this reduction of resources. The sector has emerged as a distinctive one within the education field and has been characterised as a fourth estate in addition to the primary, secondary and tertiary sectors. It is from this sector that much of the growth in China Mainland has emanated, particularly Baptist University and HKUSPACE. The sector has also been pivotally involved in the growth of the community college sector since 2000 that has delivered on government's policy to double the provision of post-secondary education from $30 \%$ to $60 \%$ of the age group. The baseline $30 \%$ included the $18 \%$ in funded universities, funded sub-degree programmes (for which funding is now progressively being removed) and subsidised overseas students. This growth has delivered on government policy five years ahead of schedule and at little cost to the public purse other than via support of students, interest free loans and land grants. Nevertheless, a number of institutions are understood to be struggling with loan payments as these are over a ten year period and it is difficult to charge fees at too high a level to recoup this entirely from the students in this period. Moreover, the falling demographics at secondary age groups means that supply and demand are in equilibrium and in fact demand may fall. For this sector therefore the ability to 
attract overseas students would in fact be important but the constraints, first of visa policies (which have now been somewhat but not wholly relaxed) and secondly of being able to offer student residential accommodation, have militated against significant growth in overseas numbers.

The policy is therefore at an impasse; those self-financed institutions with the motivation to expand cannot easily do so while the established institutions have probably expanded as much as they wish to - although even then the constraint on accommodation is a serious one. The policy does not help because it is affected by other policies. For inbound students there have been visa restrictions and even now, for the lifelong learning sector there is a $10 \%$ quota, continuing restrictions on part time students coming to Hong Kong and restrictions on students being able to study non-local courses in Hong Kong. As we have seen this latter provision does not apply in Singapore nor in Malaysia and given the heavy import penetration of overseas courses in Hong Kong this is not a helpful restriction since it would be a simple matter to expand numbers on these courses as they already exist. Partly, government thinking on non-local courses has been conflated with concerns on quality. Rightly, government has placed an emphasis on assuring the quality of private sector programmes. That sector has complained that the university sector has unfair advantages in being self-accrediting and so government has felt obliged to provide something of a level playing field and has imposed a Qualifications Framework to regulate both sectors with parallel mechanisms to ensure this. At first this will apply only to local awards but in time should extend also to non-local awards at which stage the development of what has been termed a 'secondary hub' may be feasible.

\section{Conclusions}

To conclude, this study has shown the extent of non-local provision of higher education in Hong Kong by the lifelong learning sector in association with overseas institutions and that this is a significant proportion of the total in Hong Kong. It has also been demonstrated that this factor does not appear to have been taken into account by government in developing its education hub policy. It has to be questioned whether a territory that is a net importer can have a capacity to export. The questionnaire survey has shown the range of motivating factors for overseas institutions that are not only financial but related to internationalisation - an attitude shared by Hong Kong higher education institutions. It has also shown that most institutions are very active world-wide and not just in their own region so that Hong Kong is quite mono-directional in this respect as it offers programmes elsewhere only in China Mainland. Having said that, it is reasonably successful at so doing compared to the big players and the low base it starts from. All those experts surveyed consider that Hong Kong is well placed to develop as an education hub and seem surprised that more has not been done.

The policy analysis demonstrated that the policy has not been fully discussed as to implications and represents exhortation by government rather than a blueprint for implementation. The contributions from the interviews have given a number of insights into the policy process and its limitations. The policy has not been very effective because it has lacked substantive engagement with those who might deliver it so as to ensure success. It has also been somewhat vague rather than establishing achievable targets other than in the full time, funded university sector where some expansion has been achieved. The contrasts with the leading providers (USA, UK, Australia) in terms of scale are stark and even in the region Hong Kong is well behind leaders such as Singapore and Malaysia. However, the policy levers open to the Hong Kong Government are more limited than Singapore's given the latter has been described as 'developmental state' in which government strongly steers and directs policy in contrast to Hong Kong's laissez-faire approach which eschews direct intervention and seeks a minimal role to ensure a level playing field and let the market decide. In the case of education, however, there is some ambiguity as to what the market is and the dimensions of the playing field.

\section{References}

Ashton, D. (2002). The Hong Kong Vocational System at the Crossroads, pp. 339-360 in Lifelong Learning in Action: HK Practitioners Perspective, ed. by Cribbin J. \& Kennedy, P. Hong Kong. HKU Press.

Ashton, D. \& Green, F. (1996). Education, Training and the Global Economy, Cheltenham, Edward Edgar.

Ashton, D. Green, F. James, D. and Sung, J. (1999). Education and Training for Development in East Asia. London. Routledge.

Belfield, C. (2000). Economic Principles for Education: Theory \& Evidence, Chattenham, Edward Edgar. Burns, J. (2004). Government Capacity and the Hong Kong Civil Service, Hong Kong, Oxford University Press.

Cheng Y.C. et.al March. (2009). A technical research report on the development of Hong Kong as a regional education hub. HKIED Internal Report. (unpublished). 
Coleman, J. (1997). Social Capital in the Creation of Human Capital in Education: Culture, Economy and Society ed. Halsey et al, Oxford, OUP.

Cribbin, J. (2002). Growth and Development of Lifelong Learning in Hong Kong, pp 15-34 in Lifelong Learning in Action: Hong Kong Practitioners' Perspectives, edited by Cribbin, J and Kennedy, P, Hong Kong, HKU Press.

Field, J. (2005). Social Capital and Lifelong Learning. Policy Press, Bristol.

Gardner, M. (2006). Launch of Committee for Melbourne Higher Education Taskforce White Paper and Global Universities Cities Index.

http://www.rmit.edu.au/browse;ID=1c8c7ugp2fby;STATUS=A?QRY=global\%20university\%city\%20index\&ST YPE-ENTIRE (accessed 21/3/08).

Jarvis, P. (2002). Higher Education and the Learning Society pp.293-306 in Cribbin, J. and Kennedy, P. (Eds). Lifelong Learning in Action: HK Practitioners’ Perspectives. HKU Press, Hong Kong.

Johnes, G. (2004). The Global value of education and training exports to the UK economy. British Council Report April 2004.

Kerr, C., Dunlop, J., Harbison, F. \& Meyers, C. (1962). Industrialism and Industrial Man, London Heinemann.

Kerr, C., Dunlop, J., Harbison, F., \& Meyers, C. (1971). Postscript to Industrialism and Industrial Man, International Labour Review 103, 519-540.

Knight, J. (2002). Trade in Higher Education Services: the implications of GATS in Observatory on Borderless Higher Education, Report March 2002.

Knight, J. (2003). GATS, Trade and Higher Education Perspective 2003 - where are we? In Observatory on Borderless Higher Education, Report May 2003.

Li, F. and Morgan W.J. (2008). Private Higher Education in China: access to higher education and the acquisition of labour market qualifications by low-income students, in Education, Knowledge and Economy, vol2, No.1 March 2008, pp 27-37.

Marginson, S. (1999). After globalization: emerging politics of education. In J. Education Policy, 1999, vol. 14, no. 1, 19-31.

Marginson, S. (2006). Dynamics of national and global competition in higher education. Higher Education 52: 1-39.

Mok, K.H. (2005 (a)). Globalisation - Restructuring: University Merging and Changing governance in China in Higher Education 50, 57-88.

Mok, K.H. (2005 (b)). Riding over Socialism and Global Capitalism: changing education governance and social policy paradigm in post-Mao China, in Comparative Education 41, 2, pp. 217-242.

Mok, K.H. and Currie, J. (2002). Reflections on the Impact of globalisation on Educational Restructuring in Hong Kong. In Mok, J.H. and Chan, D.K.K. Globalisation and Education: the quest for quality education in Hong Kong. Hong Kong, HKU Press.

Mok, K.H. and Tan, J. (2004). Globalization and Marketization in Education, Chattenham, Edward Edgar.

Naidoo, R. (2007). Higher Education as a Global Community in Observatory on Borderless Higher Education Report, February 2007.

Postiglione, G. (2001).China's Expansion, Consolidation and Globalisation in International Higher Education, 24.

Postiglione, G. (2003). Universities for Knowledge Economies: Hong Kong and the Chinese Mainland within Globalization and Decentralization. In Mok, J. Centralization and Decentralization: Educational Reforms and Changing Governance in Chinese Societies. Hong Kong, Kluwer.

Putnam, R. (2002). Democracies in flux: the evolution of social capital in Contemporary Society. OUP. Oxford.

Reich, R. (2004). The Higher Education Policy Institute Lecture, 2004.

At BBC News website. http://www.news.bbc.co.uk/2/hi/uk_news/education/3564531.stm. London, BBC.

Scott, I. (2005). Public Administration in Hong Kong, Singapore, Marshall Cavendish.

Siu, H., Wong. R., Faure, D. (2005). Re-thinking Hong Kong's Human Resources and Competitiveness: A Pre-Policy Study. Hong Kong Institute for the Humanities and Social Sciences, HKU, Hong Kong. 
TDC. (2005). Export Potential of Hong Kong's Educational Services,http://www.tdctrade.com/econforum/tdc/tdc050601.htm (accessed 30/12/07);

Thomas, E. (2007). Welcome Address, Realising the Global University: International Strategies for a Changing world; World Universities Network and Observatory for Borderless Higher Education Conference held in London, November $15^{\text {th }} 2007$;

Tilak, J.B. (2001). Building Human Capital, Washington World Bank Institute.

Tilak, J.B. (2003). Vocational Education \& Training in Asia. Journal of Educational Planning and Administration XVII (i) pp.53-67.

UGC. (1996). Higher Education in Hong Kong, Hong Kong, University Grants Committee.

UGC. (2002). Higher Education in Hong Kong. Report of the University Grants Committee. March 2002 (the Sutherland Report), Hong Kong, UGC.

UGC. (2004). Hong Kong Higher Education: To Make a Difference, To Move with the Times. Hong Kong, UGC. Wolf, A. (2002). Does Education Matter? Myths about education and economic growth. London, Penguin.

Wong, O. (2005). article in Ta Kung Pao, November $1^{\text {st }}, 2005$.

Woodhall, M. (1997). Human Capital Concepts in Halsey et al. Education: culture, economy and society. Oxford, OUP.

Young, E. and Lee, J. (2007). Trans-national Higher Education in a Globalized World: The Hong Kong Experience. Paper at the Conference on Leadership for Globalization in Higher Education: Lessons and Opportunities, Curtin University of Technology, Perth, Australia, December $5^{\text {th }}-7^{\text {th }} 2007$.

\section{Annex 1}

Selected Statistics from Research Study

Numbers of students by academic level in the Registered and Exempted categories for 1999 and 2005

\begin{tabular}{|l|l|l|l|}
\hline 1999 & Registered & Exempted & Total \\
\hline Bachelors & 3807 & 4642 & 8449 \\
\hline Masters & 9380 & 3976 & 13356 \\
\hline Doctorate & 377 & 90 & 467 \\
\hline Others & 4586 & 1144 & 5730 \\
\hline Total & 18150 & 9852 & 28002 \\
\hline
\end{tabular}

\begin{tabular}{|l|l|l|l|}
\hline 2005 & Registered & Exempted & Total \\
\hline Bachelors & 8479 & 14252 & 22731 \\
\hline Masters & 7186 & 7385 & 14571 \\
\hline Doctorate & 632 & 353 & 985 \\
\hline Others & 6426 & 5277 & 11703 \\
\hline Total & 22723 & 27627 & 49990 \\
\hline
\end{tabular}

*2 records without title of degree for 1999 and 30 in 2005, information in Chinese or not given. Figures for these records have been added into others category, so may slightly skew data.

Number of students graduating in the categories above in 1999 and 2005

\begin{tabular}{|l|l|l|l|}
\hline 1999 & Registered & Exempted & Total \\
\hline Bachelors & 1071 & 1388 & 2459 \\
\hline Masters & 1817 & 590 & 2407 \\
\hline Doctorate & 5 & 0 & 5 \\
\hline Others & 1337 & 121 & 1458 \\
\hline Total & 4230 & 2099 & 6329 \\
\hline \multicolumn{4}{|l|}{} \\
\hline 2005 & Registered & Exempted & Total \\
\hline Bachelors & 3369 & 4287 & 7656 \\
\hline Masters & 1756 & 1604 & 3360 \\
\hline Doctorate & 49 & 16 & 65 \\
\hline Others & 3612 & 993 & 4605 \\
\hline Total & 8786 & 6900 & 15686 \\
\hline
\end{tabular}


Numbers by country in the Registered and Exempted categories in 1999 and 2005

\begin{tabular}{|l|l|l|l|}
\hline 1999 & Registered & Exempted & Total \\
\hline Australia & 6196 & 4242 & 10438 \\
\hline Canada & 122 & 0 & 122 \\
\hline China & 0 & 788 & 788 \\
\hline UK & 11120 & 4505 & 15625 \\
\hline USA & 639 & 317 & 956 \\
\hline Other & 73 & 0 & 73 \\
\hline Total & 18150 & 9852 & 28002 \\
\hline \multicolumn{5}{|l|}{} \\
\hline 2005 & Registered & Exempted & Total \\
\hline Australia & 10355 & 7110 & 17465 \\
\hline Canada & 209 & 0 & 209 \\
\hline China & 421 & 2159 & 2580 \\
\hline UK & 10329 & 17088 & 27417 \\
\hline USA & 918 & 851 & 1769 \\
\hline New Zealand & 0 & 59 & 59 \\
\hline Other & 491 & 0 & 491 \\
\hline Total & 22723 & 27267 & 49990 \\
\hline
\end{tabular}

Numbers by country and by academic level in the Registered and Exempted categories in 1999 and 2005

\begin{tabular}{|l|l|l|l|l|l|}
\hline 1999 & Bachelors & Masters & Doctorate & Others & Total \\
\hline Australia & 5809 & 2730 & 86 & 1813 & 10438 \\
\hline Canada & 0 & 105 & 0 & 17 & 122 \\
\hline China & 478 & 296 & 0 & 14 & 788 \\
\hline UK & 1834 & 9764 & 381 & 3646 & 15625 \\
\hline USA & 315 & 458 & 0 & 183 & 956 \\
\hline Other & 13 & 3 & 0 & 57 & 73 \\
\hline Total & 7633 & 12681 & 467 & 7207 & 28002 \\
\hline
\end{tabular}

\begin{tabular}{|l|l|l|l|l|l|}
\hline 2005 & Bachelors & Masters & Doctorate & Others & Total \\
\hline Australia & 8765 & 4843 & 532 & 3325 & 17465 \\
\hline Canada & 4 & 119 & 0 & 86 & 209 \\
\hline China & 363 & 55 & 38 & 2124 & 2580 \\
\hline New Zealand & 0 & 59 & 0 & 0 & 59 \\
\hline UK & 12890 & 8902 & 415 & 5210 & 27417 \\
\hline USA & 510 & 513 & 0 & 746 & 1769 \\
\hline Other & 199 & 80 & 0 & 212 & 491 \\
\hline Total & 22731 & 14571 & 985 & 11703 & 49990 \\
\hline
\end{tabular}

\section{Types of CE provider from 2001 HK Government Survey}

\begin{tabular}{|l|r|r|}
\hline Type of course provider & $\begin{array}{l}\text { Programmes Percentage } \\
\text { of } \\
(\%)\end{array}$ & $\begin{array}{l}\text { Students Percentage of } \\
(\%)\end{array}$ \\
\hline UGC-funded Institutions & $7 \%$ & $7 \%$ \\
\hline CE units of UGC Institutions & $22 \%$ & $22 \%$ \\
\hline Government-related or statutory bodies (eg. VTC) & $14 \%$ & $17 \%$ \\
\hline Commercial associations / Trade unions / Trade organizations & $21 \%$ & $21 \%$ \\
\hline Voluntary organizations / Social services agencies & $4.50 \%$ & $2.50 \%$ \\
\hline Government departments & $3 \%$ & $6 \%$ \\
\hline Others (eg. Private schools) & $21 \%$ & $12 \%$ \\
\hline Professional bodies & $3 \%$ & $9 \%$ \\
\hline Non-government organizations providing in-house training to employees & $2 \%$ & $2 \%$ \\
\hline Overseas institutes & $0.50 \%$ & \\
\hline
\end{tabular}




\begin{tabular}{|c|c|c|c|c|c|c|c|c|c|c|c|c|c|}
\hline \multicolumn{14}{|c|}{$\begin{array}{l}\text { Federation for Continuing Education in Tertiary Insti } \\
\text { Statistics of Programmes in Continuing and Professio } \\
2002 \text { / } 03 \text { (for the period from } 1 \text { July to } 30 \text { June) }\end{array}$} \\
\hline & & HKU & HKBU & Caritas & CUHK & $\mathrm{LU}$ & PolyU & VTC & CityU & OUHK & HKUST & HKIEd & \\
\hline & & SPACE & SCE & CAHES & SCE & LIFE & $\begin{array}{l}\text { HKCC } \\
\& \\
\text { SPEED }\end{array}$ & CPD & SCOPE & LiPACE & OPCE & CPE & Total \\
\hline \multirow{3}{*}{ Postgraduate } & $\begin{array}{l}\text { No. of } \\
\text { Programmes }\end{array}$ & 59 & 10 & 4 & 7 & $\mathrm{n} / \mathrm{a}$ & 7 & $\mathrm{n} / \mathrm{a}$ & 18 & 6 & $\mathrm{n} / \mathrm{a}$ & 1 & 112 \\
\hline & $\begin{array}{l}\text { Student } \\
\text { Headcounts }\end{array}$ & 3,903 & 1,446 & 99 & 126 & $\mathrm{n} / \mathrm{a}$ & 174 & $\mathrm{n} / \mathrm{a}$ & 1,180 & 1,864 & $\mathrm{n} / \mathrm{a}$ & 34 & 8,826 \\
\hline & $\begin{array}{l}\text { Full-time } \\
\text { Equivalent }\end{array}$ & 1,905 & 706 & 50 & 48 & $\mathrm{n} / \mathrm{a}$ & 34 & $\mathrm{n} / \mathrm{a}$ & 571 & $\mathrm{n} / \mathrm{a}$ & $\mathrm{n} / \mathrm{a}$ & 17 & 3,331 \\
\hline \multirow{3}{*}{ Undergraduate } & $\begin{array}{l}\text { No. of } \\
\text { Programmes }\end{array}$ & 40 & 7 & 6 & 4 & 1 & 8 & 3 & 17 & 2 & $\mathrm{n} / \mathrm{a}$ & $\mathrm{n} / \mathrm{a}$ & 88 \\
\hline & $\begin{array}{l}\text { Student } \\
\text { Headcounts }\end{array}$ & 7,550 & 6,158 & 632 & 381 & 68 & 734 & 233 & 2,562 & 646 & $\mathrm{n} / \mathrm{a}$ & $\mathrm{n} / \mathrm{a}$ & 18,964 \\
\hline & $\begin{array}{l}\text { Full-time } \\
\text { Equivalent }\end{array}$ & 3,818 & 3,828 & 316 & 234 & 6 & 171 & 2 & 1,410 & $\mathrm{n} / \mathrm{a}$ & $\mathrm{n} / \mathrm{a}$ & $\mathrm{n} / \mathrm{a}$ & 9,785 \\
\hline \multirow{3}{*}{ Sub-degree } & $\begin{array}{l}\text { No. of } \\
\text { Programmes }\end{array}$ & 198 & 47 & 75 & 115 & 10 & 4 & 21 & 132 & 30 & 17 & 136 & 785 \\
\hline & $\begin{array}{l}\text { Student } \\
\text { Headcounts }\end{array}$ & 24,388 & 7,306 & 6,218 & 9,888 & 780 & 1,211 & 2,696 & 6,336 & 12,306 & 461 & 3,466 & 75,056 \\
\hline & $\begin{array}{l}\text { Full-time } \\
\text { Equivalent }\end{array}$ & 9,252 & 4,490 & 5,819 & 3,001 & 662 & 1,018 & 1,422 & 1,862 & 849 & 76 & 1,517 & 29,968 \\
\hline \multirow{3}{*}{ Short courses } & $\begin{array}{l}\text { No. of } \\
\text { Programmes } \\
\end{array}$ & 541 & 1,727 & 828 & 581 & 3 & 266 & 43 & 324 & 16 & 19 & 301 & 4,649 \\
\hline & $\begin{array}{l}\text { Student } \\
\text { Headcounts }\end{array}$ & 25,070 & 41,023 & 100,381 & 33,414 & 25 & 6,590 & 1,392 & 14,222 & 455 & 206 & 9,220 & 231,998 \\
\hline & $\begin{array}{l}\text { Full-time } \\
\text { Equivalent }\end{array}$ & 2,562 & 482 & 9,221 & 1,419 & 3 & 751 & 3 & 879 & 12 & 18 & 275 & 15,625 \\
\hline \multirow{3}{*}{ Total } & $\begin{array}{lr}\text { No. of } \\
\text { Programmes }\end{array}$ & 838 & 1,791 & 913 & 707 & 14 & 285 & 67 & 491 & 54 & 36 & 438 & 5,634 \\
\hline & $\begin{array}{l}\text { Student } \\
\text { Headcounts }\end{array}$ & 60,911 & 55,933 & 107,330 & 43,809 & 873 & 8,709 & 4,321 & 24,300 & 15,271 & 667 & 12,720 & 334,844 \\
\hline & $\begin{array}{l}\text { Full-time } \\
\text { Equivalent }\end{array}$ & 17,537 & 9,506 & 15,406 & 4,702 & 671 & 1,974 & 1,427 & 4,722 & 861 & 94 & 1,809 & 58,709 \\
\hline
\end{tabular}

Non-local provision compared to UGC provision, 1999 and 2005

(A)

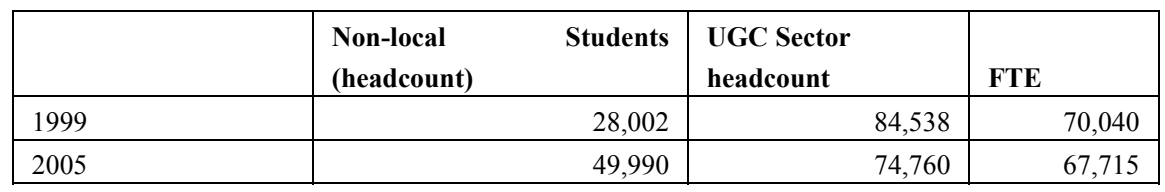

(B) Comparison by Level of Programmes

\begin{tabular}{|l|r|r|r|r|}
\hline $\begin{array}{l}\text { Non-local } \\
\text { (by Headcount) }\end{array}$ & \multicolumn{2}{l|}{ UGC(by FTE) } \\
\hline & 1999 & 2005 & 1999 & 2005 \\
\hline Bachelors & 8,449 & 22,731 & 45,523 & 50,009 \\
\hline Masters & 13,356 & 14,571 & 6,062 & 3,428 \\
\hline Doctoral & 467 & 985 & 3,607 & 5,208 \\
\hline Other & 5,430 & 11,703 & 14,848 & 9,070 \\
\hline
\end{tabular}


Graduate outputs, overseas programmes and UGC institutions

\begin{tabular}{|l|l|l|}
\hline & Non-Local (headcount) & UGC (headcount) \\
\hline & $\mathbf{1 9 9 9}$ & $\mathbf{1 9 9 9}$ \\
\hline Bachelor & 2,459 & 14,600 \\
\hline Master & 2,407 & 4,768 \\
\hline Doctor & 5 & 1,352 \\
\hline Others & 1,456 & 10,624 \\
\hline Total & $\mathbf{6 , 3 2 7}$ & $\mathbf{3 1 , 3 4 4}$ \\
\hline & & \\
\hline & $\mathbf{2 0 0 5}$ & $\mathbf{2 0 0 5}$ \\
\hline Bachelor & 7,656 & 15,719 \\
\hline Master & 3,360 & 3,553 \\
\hline Doctor & 65 & 1,745 \\
\hline Others & 4,605 & 5,741 \\
\hline Total & $\mathbf{1 5 , 6 8 6}$ & $\mathbf{2 6 , 7 5 8}$ \\
\hline
\end{tabular}

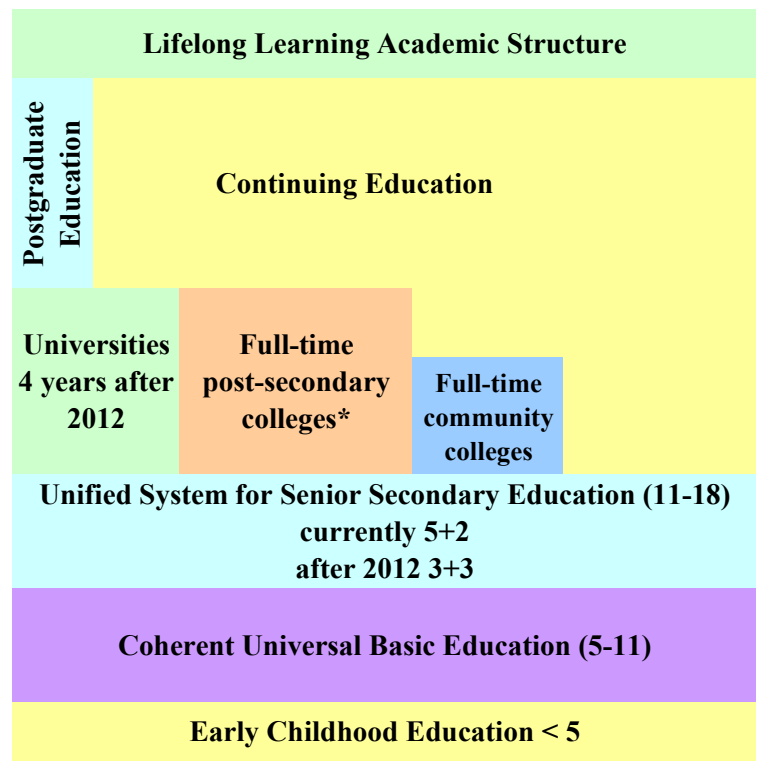

*Post-secondary colleges refer to institutions providing post-secondary courses, vocational courses and compensatory courses.

Figure 1. The educational system envisaged by the Education Commission and practice in 2007/8 (EC 2000:18) 